\title{
Assessing the Effectiveness of Remedy Outcomes of Non-judicial Grievance Mechanisms
}

\author{
Martijn Scheltema*
}

\section{Introduction}

The UN Guiding Principles, under their third pillar on access to remedy, address the question of what makes a non-judicial grievance mechanism effective as a mechanism, that is, as a means of accessing the outcome of remedy. The criteria set out in Guiding Principle 31 were based on extensive research, consultation and testing. ${ }^{1}$ The criteria provide a benchmark for designing, revising or assessing a non-judicial grievance mechanism to help ensure that it is effective in practice. Guiding Principle 31 of the Ruggie Framework states ${ }^{2}$ :

In order to ensure their effectiveness, non-judicial grievance mechanisms, both State-based and nonState-based, should be:

(a) Legitimate: enabling trust from the stakeholder groups for whose use they are intended, and being accountable for the fair conduct of grievance processes;

(b) Accessible: being known to all stakeholder groups for whose use they are intended, and providing adequate assistance for those who may face particular barriers to access;

(c) Predictable: providing a clear and known procedure with an indicative time frame for each stage, and clarity on the types of process and outcome available and means of monitoring implementation;

(d) Equitable: seeking to ensure that aggrieved parties have reasonable access to sources of information, advice and expertise necessary to engage

Martijn Scheltema is partner with Pels Rijcken \& Droogleever Fortuijn (a The Hague-based law firm), professor at Erasmus University Rotterdam and member of the governing board of ACCESS (see <www.ACCESS facility.org $>$ ). This article is based on research conducted by the author on effectiveness of remedy outcomes of non-judicial mechanisms on behalf of ACCESS and the United Nations Working Group on Human Rights.

1. See Rees, January 2008; Rees, November 2008 and e.g. recently Onuoha \& Barendrecht, December 2012, pp. 17, 20-22. Cf., e.g., Scheltema 2012a pp. 393-397.

2. The UN 'Protect, Respect and Remedy' Framework of J. Ruggie, to be found at <shiftproject.org/sites/default/files/GuidingPrinciplesBusiness HR_EN.pdf>. in a grievance process on fair, informed and respectful terms;

(e) Transparent: keeping parties to a grievance informed about its progress, and providing sufficient information about the mechanism's performance to build confidence in its effectiveness and meet any public interest at stake;

(f) Rights compatible: ensuring that outcomes and remedies accord with internationally recognized human rights;

(g) A source of continuous learning: drawing on relevant measures to identify lessons for improving the mechanism and preventing future grievances and harms;

Operational-level mechanisms should also be:

(h) Based on engagement and dialogue: consulting the stakeholder groups for whose use they are intended on their design and performance, and focusing on dialogue as the means to address and resolve grievances.

The commentary to this principle elucidates that a grievance mechanism can only serve its purpose if the people it is intended to serve know about it, trust it and are able to use it. Poorly designed or implemented grievance mechanisms can risk compounding a sense of grievance amongst affected stakeholders by heightening their sense of disempowerment and disrespect by the process.

That said, it might be of interest expanding the understanding of 'effectiveness' in the context of non-judicial grievance mechanisms to encompass not only the process of the non-judicial mechanism but also the effectiveness of the outcomes that might be achieved through them. The criteria in the Guiding Principles are limited in terms of outcomes, stating simply that they should be compatible with human rights. In this contribution, I will explore the extent to which non-judicial grievance mechanisms can and do provide for 'effective remedy' as an outcome.

However, one should realize that non-judicial grievance mechanisms, unlike judicial mechanisms, entail a large variety of different processes. As will be elucidated hereinafter, non-judicial mechanisms can vary widely in their location, form and process. Some are state-based and others function at industry/trade or company level. Furthermore, their processes differ. Some entail quasi- 
adjudicative processes, while others are dialogue-based. Moreover, even the same non-judicial mechanism might result in different outcomes turning on the case at hand. In some cases, a form of redress might be an outcome and in others, for example, a continuous dialogue between stakeholders. This results in a large variety of different (possible) remedy outcomes of non-judicial mechanisms. The obvious question arises whether elements of effectiveness of remedy outcomes are conceivable, which apply to all non-judicial mechanisms, or whether their variety is too large to find such common elements.

The contribution begins by reviewing the variety of non-judicial mechanisms to explore whether (effective) remedial outcomes of non-judicial mechanisms are a predefined set as already exists in the judicial sphere, and how far they might extend beyond that and include a broader (or just different) array of outcomes in the non-judicial sphere. To illustrate the variety of remedy outcomes in the non-judicial sphere, a range of illustrative cases is set out from different kinds of mechanism and process and considers the forms of outcome they provide.

This contribution then explores elements that might be helpful to assess whether and to what extent non-judicial grievance mechanisms can and do provide for 'effective remedy' as an outcome. Perceptions of the effectiveness of the outcomes are likely to influence the trust that stakeholders have in the mechanisms themselves and their usage.

\section{Precedents and Parallels in the Judicial Arena}

The notion of effective remedy is a well-known and reasonably developed concept in connection with international human rights law and judicial mechanisms, which is included in many regional and international human rights treaties (such as Article 2(3) ICCPR and Article 13 ECHR). Broadly speaking, it entails access to an impartial decision-maker or mechanism with the power to hear and investigate complaints and, where appropriate, to provide reparation. In this respect, it is important to distinguish between the procedural aspects involving 'access to justice' (which refers to the effectiveness of the remedial mechanisms in place and whether victims have both the opportunity and ability to access them), and the substantive 'reparation', which means the type or quantum of relief, afforded.

Other aspects of the right to a remedy have evolved out of international humanitarian law requirements regarding for instance the recording and passing on of information about the wounded, sick and the dead. In addition, human rights cases concerning amongst other things enforced disappearances have stressed the importance of the victim's right to information about the violation, particularly where the claimant is not the direct victim but another affected individual closely linked to them, for example, a member of their family. ${ }^{3}$ Similar views have been expressed by a number of global and regional human rights treaty bodies. With respect to the United Nations treaty bodies, some common strands can be identified in their approach to state obligations to provide access to remedy for human rights abuses, whether committed by public or private actors. ${ }^{4}$ They have emphasized the importance of both procedural elements, ${ }^{5}$ namely,

- conducting prompt, thorough and fair investigations;

- $\quad$ providing access to prompt, effective and independent remedial mechanisms, established through judicial, administrative, legislative and other appropriate means;

and outcome-oriented elements, namely,

- imposing appropriate sanctions, including criminalizing conduct and pursuing prosecutions where abuses amount to international crimes; and

- $\quad$ providing a range of forms of appropriate reparation, such as compensation, restitution, rehabilitation and changes in relevant laws.

The concept of effective remedy has been strongly influenced by the law of state responsibility and, as a general rule, follows its emphasis on compensatory justice, which means putting the victim back in (or as close to) the position it would have been in but for the violation. Appropriate reparation in each case will turn on the right at issue and nature of the violation. ${ }^{6}$

\section{Considerations in the Non-judicial Arena}

The obvious question arises whether this concept of effective remedy might be transposed wholesale to non-judicial grievance mechanisms without further consideration. A number of considerations suggest not. Judicial mechanisms within any jurisdiction will offer similar processes, or at least processes that are highly aligned with each other. With regard to human rights violations, they are intended to provide reparation for

3. Promotion of all human rights, civil, political, economic, social and cultural rights, including the right to development, Addendum to the Ruggie Framework of 15 May 2009, A/HRC/11/13/Add.1, 6. Cf. Guiding Principle 26.

4. Promotion of all human rights, civil, political, economic, social and cultural rights, including the right to development, Addendum to the Ruggie Framework of 15 May 2009, A/HRC/11/13/Add.1, 2.

5. Promotion of all human rights, civil, political, economic, social and cultural rights, including the right to development, Addendum to the Ruggie Framework of 15 May 2009, A/HRC/11/13/Add.1, 3.

6. Promotion of all human rights, civil, political, economic, social and cultural rights, including the right to development, Addendum to the Ruggie Framework of 15 May 2009, A/HRC/11/13/Add.1, 2; Van Genugten et al. 2009, pp. 1-79 and from the perspective of state responsibility and private-public interaction: Van Genugten \& Jägers 2011, pp. 253-278. 
victims insofar as the human rights in question are reflected in applicable law; to create a level of deterrence to others who may commit similar violations and - at least in the case of criminal proceedings - to provide wider justice and protections for society. This reflects the broader role of judicial mechanisms in ensuring the rule of law.

Non-judicial mechanisms entail different mechanisms ${ }^{7}$ :

1. mechanisms at the company or project level to which impacted individuals and groups (for example, workers, communities etc.) can bring complaints; ${ }^{8}$

2. mechanisms linked to industry and multi-stakeholder initiatives (for example, the Fair Labour Association, Ethical Trading Initiative, Social Accountability International, International Council of Toy Industries, Voluntary Principles on Security and Human Rights, Global Framework Agreements);

3. national mechanisms based in government (for example, National Contact Points of OECD Member States, consumer complaints bodies) ${ }^{9}$

4. national mechanisms that are state supported but independent of government (for example, ombudsman offices, labour dispute-resolution offices, national human rights institutions); and

5. regional and international mechanisms (for example, ILO-based mechanisms, the Compliance Advisor/Ombudsman [CAO] of the World Bank Group).

As this reflects, some non-judicial grievance mechanisms lack any state involvement. ${ }^{10}$ Others are administered by the state or a state agency and as such can be seen as contributing to the implementation of the state duty to protect against human rights abuses. In addition, some non-judicial mechanisms, both state-based and non-state-based, entail investigatory and quasiadjudicative processes that involve reaching findings or conclusions and recommendations. These mechanisms come closer to resembling judicial (state-based) mechanisms through this quasi-adjudicative function, than do those mechanisms that are premised primarily on seeking dialogue-based solutions, insofar as they entail some assessment of the extent to which a company has complied with the relevant set of 'rules'. ${ }^{11}$ This might suggest that some of the criteria or definitions for effective remedy in relation to judicial mechanisms may also be applicable in the case of these non-judicial mechanisms.

7. See, e.g., Rees \& Vermijs, January 2008; Linder et al. 2013 to be found at <http://bim.lbg.ac.at/en/news/extrajudicial-complaint-mechanismsconflict-resolution-between-business-and-human-rights-0>

8. See for an extensive analysis of these mechanisms Wilson \& Blackmore 2013, to be found at <http://pubs.iied.org/16529|IED.html>.

9. See, e.g., on two NCP cases Backer 2009, pp. 30-38, to be found at $<$ http://papers.ssrn.com/sol3/papers.cfm?abstract_id=1427883>.

10. However, Guiding Principle 28 requires states to facilitate access to effective non-state-based grievance mechanisms dealing with businessrelated human rights harms.

11. However, it should be noted that some of the mechanisms might perform both functions, i.e. dialogue based and quasi-adjudicative (e.g. the CAO/World Bank ombudsman and the NCPs).
That said, other criteria or definitions for effective remedy in connection with judicial mechanisms would clearly not be applicable in the case of non-judicial mechanisms, such as criminal punishment or sanctions. Moreover, the necessity of enforcement of the outcomes of judicial mechanisms does not exist in connection with all non-judicial grievance mechanisms and enforceability is sometimes not even strived after. Therefore, effectiveness of remedy outcomes also turns on the processes applied in the non-judicial mechanisms involved. These processes might entail amongst others fact finding/ investigation, dialogue and monitoring. Furthermore, some non-judicial mechanisms (especially dialoguebased mechanisms) are voluntary in the sense that stakeholders cannot be forced to take use or take part in the mechanism or to be bound by its outcomes without their consent, unlike judicial mechanisms, which might provide redress against the will of a perpetrator.

Given the variety of non-judicial grievance mechanisms and processes, the question arises to what extent effective remedial outcomes of non-judicial mechanisms are a predefined set (as already exists in the judicial sphere). In other words, is it feasible to identify common elements of effectiveness that apply to all different types of outcome resulting from the various kinds of non-judicial mechanism and process? To facilitate further thinking on this question, a few cases are described to illustrate the variety of outcomes resulting from different types of non-judicial mechanisms.

\subsection{OECD National Contact Point Intex and Nidera Cases}

In the Intex case considered by the Norwegian NCP, the non-governmental organization (NGO) Future In Our Hands had lodged a complaint against Intex for violating indigenous peoples' human and environment rights. After the NCP received the complaint in 2009, the NCP commissioned a fact-finding mission conducted by independent experts in accordance with mutually agreed terms in order to examine the allegations. The NCP concluded in its final statement that Intex neglected to consult the 'affected' indigenous groups or inform the stakeholders of the possible environmental damages. In the view of the NCP, Intex should have systematically investigated how many indigenous people would be affected by their activities and consult them. Intex had conducted impact assessments that identified and addressed some of the environmental and social points discussed in the complaint; however, according to the NCP, the analysis of Intex is lacking on some important points such as more detailed management and monitoring plans. Furthermore, Intex was accused of bribery in relation to its mining exploration permits. The NCP concluded that it could not find any evidence indicating any involvement in bribery or corruption. However, more investigation was deemed necessary in order to clarify certain transactions of Intex with other parties. The NCP made several recommendations where Intex could make improvements, among others, with regard to consultation, disclosure and transparency, and its 
grievance mechanism. In addition, as overall assessment, the NCP stated that due diligence processes apply in all states of production including the planning of activities. $^{12}$

However, it should be noted that NCPs might also facilitate dialogue-based processes. For example, in a case considered by the Dutch NCP, a complaint has been filed by a group of Argentine and Dutch NGOs, which alleged that Nidera has abused the human rights of temporary workers at its corn seed processing operations in Argentina. After a series of meetings enabled by the NCP in which the parties discussed the issues of the complaint, an agreement was reached. As part of the agreement, Nidera strengthened its human rights policy, formalized human rights due diligence procedures for temporary rural workers, and allowed the NGOs to monitor its Argentine corn seed operations through field visits. A final statement issued by the Dutch NCP on 5 March 2012 confirmed the outcome of the dialogue between the parties. ${ }^{13}$

These NCP cases entail a state-based mechanism that requires parties' agreement to participate in dialogue, but can result in a public final statement. In both cases considered here, the process entailed dialogue-based elements as well as fact-finding and investigation. The first case reveals elements of an adjudicative process too. The substantive outcome in the first case was an assessment and recommendation made in the final statement of the NCP. The assessment entailed that Intex had insufficiently consulted indigenous people, but no evidence indicating any involvement in bribery or corruption could be found. The NCP made several recommendations for improvement, amongst others, with regard to consultation, disclosure and transparency, and the company-based grievance mechanism. Therefore, this outcome was both retrospective and forward looking and as the public statement is issued without consent of the parties, it is unclear whether it has been accepted by the parties. In the second case, the process resulted in the strengthening of the human rights policy of the company and in a formalized human rights due diligence process. This outcome is forward looking and was accepted by both parties. In both cases, the mechanisms entailed no means of enforcement, although the outcome is monitored by an NGO in the second case.

\subsection{Malawi Human Rights Commission Terrastone Case}

In a dispute between Terrastone Limited, operating the Njuli Quarry, Olira Club, a village organization set up by concerned villages surrounding the Njuli Quarry and the Malawian Ministry of Energy and Mining, the Malawi Human Rights Commission (MHRC) had received a complaint on behalf of Olira Club, stating that Terrastone was polluting the area with its opera-

12. This case is to be found at <www.regjeringen.no/en/sub/styrer-radutvalg/ncp_norway/news/report_intex.html?id=664912> and <www. regjeringen.no/upload/UD/Vedlegg/ncp/intex_final.pdf>.

13. This case may be found at $\left.<w w w . o e c d w a t c h . o r g / c a s e s / C a s e \_220\right\rangle$. tions, affecting five villages and making it uninhabitable for the communities. ${ }^{14}$

Following the complaint, MHRC conducted fact-finding/investigation activities at the quarry and in the villages, interviewing both Terrastone and community representatives. On the basis of its findings, the MHRC confirmed most of the allegations made by the complainants, observing that the activities at the quarry were having an impact on the environment and constituted a disruption of peoples' livelihoods and a threat to their health and safety. In addition, the MHRC had found that the quarry had not complied with requisite legal regulations and that the Ministry of Energy and Mining had not effectively complied with its obligation to make sure companies follow the environmental standards. After engaging with the communities and Terrastone to assess their respective needs, MHRC facilitated the discussions between the two parties on how to move forward. The Ministry of Energy and Mining conducted independent inspections of the quarry and issued a stop order to the quarry authorities, directing them to take effective measures to reduce and restore environmental damage. Furthermore, community engagement was continuously facilitated. Compliance was monitored by MHRC during round table discussions with the quarry authorities, community representatives and government officials.

This case entails a state-supported mechanism with a hybrid model that combines fact-finding and investigation with a dialogue-based process. The substantive outcome has brought about a continuous dialogue between parties and as a result of the investigations a stop order by the authorities inducing the reduction and restoration of environmental damage. The outcome was both forward looking and retrospective (as to the investigation) and accepted by both parties with regard to the continuous dialogue. The reduction and restoration of environmental damage was government induced. The mechanism entailed no means of enforcement. Monitoring took place by the human rights commission, however, only during the process.

\subsection{Worldbank CAO Ombudsman NSEL Case}

After numerous community members in Chichigalpa, Nicaragua, suffered kidney-related illnesses, which they believe are related to their work in the sugar cane industry, the Washington, DC-based NGO, the Center for International Environmental Law, filed a complaint with the Compliance Advisor Ombudsman of the World Bank Group. ${ }^{15}$ The complaint was made on behalf of community members, including former workers of Nicaragua Sugar Estates Limited (NSEL), which was an International Finance Corporation of the World Bank Group client and operator of an agro-energy complex in Chichigalpa. In a CAO-led dispute-resolution process, NSEL and the community representatives jointly agreed to a framework that provided for a dia-

14. To be found at <www. accessfacility.org $>$

15. To be found at <www.cao-ombudsman.org/cases/case_detail.aspx? $\mathrm{id}=82>$. 
logue-based approach to help address the issues of concern. The parties agreed to action points that included an independent study by Boston University School of Public Health into the cause of chronic kidney disease (CKD), improvements in care for affected community members who are sick and unable to work, or families of those who have died, and initiation of income-generating projects to support alternate livelihoods for those suffering from CKD. Since 2009, NSEL and community representatives have met regularly through a robust dialogue process facilitated by the CAO to evaluate progress towards implementing agreed action items and discuss next steps.

This case entails an international mechanism (CAO of the World Bank) and a voluntary participation model. The process was dialogue based. The substantial outcome was an improvement in care of those suffering from CKD (and their families) and income-generating projects to support alternative livelihood for those suffering from CKD. The outcome was forward looking and accepted by both parties. The mechanism entailed no means of enforcement of the outcome. However, the Ombudsman reports to the World Bank President. The President and Board of Directors have the power to decide whether to cease their support for a project in the event the Ombudsman finds there is persistent noncompliance with IFC/MIGA standards.

\subsection{Fair Labour Association Estofel Case}

After the closure of Estofel S.A. in November 2007, the

company had failed to pay severance benefits required by Guatemalan law. ${ }^{16}$ Concerns were raised by former Estofel S.A. workers to the Fair Labour Association (FLA)-affiliated company, PVH, who had sourced directly from the factory until a few months before the closure. Shortly after the closure, the Commission for the Verification of Corporate Codes of Conduct (COVERCO) had pressed Estofel S.A. for full severance payments. In 2008, the FLA had received third-party complaints from eight former workers at Estofel S.A. To manage the resolution of the case, FLA and the Workers Rights Consortium (WRC) organized an ad hoc multi-stakeholder group consisting of representatives of all of the participants mentioned above. COVERCO was tasked with determining the amount of severance due to each of the dismissed workers, and the WRC and the FLA developed an outreach plan for finding these workers. COVERCO, representatives of Estofel and legal counsel formed a working group to address discrepancies in the list of workers eligible to receive payments and the amounts to be paid. The group agreed on the workers who would be paid and the amount each would receive. COVERCO was able to reach almost 95 percent of the 974 workers, and 860 workers received 89.9 percent of the amount that COVERCO deemed workers should have received in additional payments.

16. To be found at <www.fairlabor.org/report/estofel-sa-factory-guate mala>.
This case entails a mechanism administered by an independent third party (but with which one of the companies involved was affiliated) and a voluntary participation model with a dialogue-based process (between an ad hoc multi-stakeholder group). The substantive outcome was monetary redress in the form of (additional) severance payments. The outcome was retrospective and accepted by all parties. The mechanisms entail no means of enforcement. The severance has been paid.

\subsection{Neutral Facilitator Chevron Case}

Oil company Chevron Nigeria Limited (CNL) is in a joint venture with the government of Nigeria, which owns a majority stake in its operations. ${ }^{17}$ Nigeria is home to numerous ethnic groups, each of them seeking to have their interests adequately represented in government. Representation of a community in government brings the ability of that community to influence policy, and with it, control over the awarding of valuable contracts and influence in the governance of regions. Disputes about representation and elections in a context of ethnic strife have triggered major outbreaks of violence, leading to deaths, displacement, looting and shutdowns of oil companies' flow stations. After a period of substantial and violent civil and social unrest in 2003, Chevron and the host communities impacted by its oil production sought to transform their relationship in a new approach based on increased dialogue, community participation, transparency and multi-stakeholder accountability. Though many issues of the conflict such as ethnic strife were beyond CNL's control, CNL was determined to create a model that would allow greater stakeholder engagement in the company's operations and its development projects, which may contribute to addressing historic grievances and create a more stable environment. CNL sought to change its perception with the communities from CNL seeing them solely as being a source of income, to a company that leaves genuine development impacts resulting from community investments. The approach they adopted, known as the GMOU (General Memorandum of Understanding), created regional development committees to provide a greater voice to communities and share ownership of community investments. As part of the approach, the parties engaged neutral dialogue facilitators to help build more durable agreements between the parties and created a single consistent platform for company/community dialogue that enables early identification and resolution of issues that arise in the course of their relationship. Since adopting this approach in 2005, the parties have jointly evaluated and then renegotiated their agreements on a periodic basis in order to identify lessons and promote continuous improvement.

This case entails a third-party-facilitated dialogue between a company and a community on a voluntary basis. The substantial outcome entailed a GMOU (a durable agreement with a consistent single platform for

17. To be found at <http://cbuilding.org/sites/cbi.drupalconnect.com/files/ Corporate $\% 20$ and $\% 20$ Community $\% 20$ Engagement $\% 20$ in $\% 20$ the $\%$ 20Niger\%20Delta_Lessons\%20Learned.pdf>. 
company/community dialogue to identify and resolve outstanding issues). The outcome was forward looking and accepted by both parties. The mechanism entails no means for enforcement.

\subsection{Table of Outcomes}

In the following table, the outcomes of the cases have been summarized to enable (a better) comparison.

Although it would need a larger sample of cases to draw clear conclusions, the foregoing elucidates a variety of processes, administered by governmental and statutory bodies, companies, international organizations and multi-stakeholder initiatives. In most cases, some voluntary element of participation is concerned. The processes all entail elements of dialogue, two (the NCP Intex and Terrastone cases) involve fact-finding/investigation and only one of them (the NCP Intex case) of (quasi-)adjudicative processes too. However, the Terrastone case entails an adjudicative process in connection with the stop order of the Ministry of Mines as well, although the Ministry was not the owner of the mechanisms or initiator of the complaint. The outcomes of all but one are forward looking and accepted by the parties involved. The cases entail no means of enforcement of the outcome. However, in the Terrastone case, a stop order resulted from the investigations of the human rights commission. Furthermore monitoring is established in some cases.

\section{Perspectives on What Constitutes an Effective Remedy Outcome of Non-judicial Grievance Mechanisms}

The overview of these few cases already reveals the variety of substantive outcomes. The outcomes range from a final statement of an NCP, to strengthening of the human rights policy and due diligence process of a company, continuous dialogue between a company and a local community and a stop order from the government, improvements in care and income-generating projects to support alternative livelihood, monetary redress and a GMOU. However, further examination will be needed to identify elements of effectiveness in the content and implementation of these outcomes as well as any patterns across them. Moreover, more case studies are needed to examine whether outcomes can be categorized into a set number of types to which common elements of effectiveness apply, or whether it might be conceivable to identify certain overarching features that any outcome would need to have in order to qualify as 'effective'. If all types of remedial outcomes need to have certain features in order to qualify as effective, and in my opinion they should, it becomes necessary to describe what these features are, including whether they are necessarily objective (for example, alignment with national law), necessarily subjective (for example, based on the perspective of those impacted) or a mixture of both.

It is therefore important to establish viable means of indentifying and testing what criteria for, or elements of, effective remedial outcomes might look like in the case of non-judicial grievance mechanisms and the extent to which they may coincide with or differ from those generally accepted with regard to judicial mechanisms. One might assess as follows:

1. the consistency of an outcome with national and international human rights laws and regulations;

2. the rights-compatibility of an outcome (see Guiding Principle 31(f));

3. whether an outcome falls within a certain predefined range of options (such as compensation, restitution, guarantees of non-repetition and providing relevant information);

4. whether business and/or local communities (and/ or their representatives) involved in a case perceive a certain outcome or set of outcomes as effective;

5. whether states classify certain outcomes as effective or support them as outcomes of a non-judicial grievance mechanism;

6. whether companies increase their efforts to respect human rights because of the existence of such mechanisms;

7. whether the outcome of a certain mechanism restores a particular individual to the enjoyment of their human rights;

8. whether the outcome of a certain mechanism improves the human rights situation more widely and whether it helps prevent or reduce future grievances and harms;

9. whether the outcomes of a certain mechanism are implemented in practice and are enforceable (the enforcement of the outcome of non-judicial mechanisms might be realized through state mechanisms [for example, through enforcing an agreement which has resulted from a non-judicial mechanism $]^{18}$ or through arbitration ${ }^{19}$ ) or being monitored, ${ }^{20}$ and

10. whether the outcome of a certain mechanism is aligned with the (possible) outcomes of other non-

18. For example, the Mediation Directive has been promulgated in the European Union (Directive 2008/52/EU, OJ 2008 L 136/3). This directive is applicable to cross-border conflicts (as mentioned in Section 2), in which at least one party (in human rights related conflicts by and large a company) has its seat in the EU. Especially Section 6 Subsection 1 of the directive is of importance. It imposes a duty on EU-member states to render agreements resulting from mediation/facilitation enforceable if parties consent to this and as far as the result is not contradictory to national law.

19. See Scheltema 2012b, pp. 189-194. Because of (Section $\vee$ of) the New York treaty on commercial arbitration (which many developing countries also have adopted), the enforcement of arbitral awards is easier than foreign judgments in member states because (Section $V$ of) the treaty prevents member states to impose other barriers on enforcement than are adopted for national arbitral awards.

20. Monitoring is considered to be important. See, e.g., Linder et al. 2013, pp. 89, 92 . 


\begin{tabular}{|c|c|c|c|c|c|c|}
\hline $\begin{array}{l}\text { Case/non- } \\
\text { judicial } \\
\text { mechanism } \\
\text { and out- } \\
\text { come }\end{array}$ & Intex & Nidera & Terrastone & NSEL & Estofel & Chevron \\
\hline $\begin{array}{l}\text { Administra- } \\
\text { tion }\end{array}$ & $\begin{array}{l}\text { State-based NCP } \\
\text { (but independent) }\end{array}$ & $\begin{array}{l}\text { State-based } \\
\text { NCP (but inde- } \\
\text { pendent) }\end{array}$ & $\begin{array}{l}\text { State supported } \\
\text { (human rights commis- } \\
\text { sion) }\end{array}$ & $\begin{array}{l}\text { International } \\
\text { organization } \\
\text { (CAO of World } \\
\text { Bank) }\end{array}$ & $\begin{array}{l}\text { Independent } \\
\text { third party (how- } \\
\text { ever, with which } \\
\text { companies were } \\
\text { affiliated) }\end{array}$ & $\begin{array}{l}\text { Company and } \\
\text { communitiy } \\
\text { together (inde- } \\
\text { pendent facilita- } \\
\text { tor) }\end{array}$ \\
\hline Process & $\begin{array}{l}\text { Hybrid; several } \\
\text { meetings but offer } \\
\text { to mediate was } \\
\text { declined }\end{array}$ & $\begin{array}{l}\text { Dialogue-based } \\
\text { (although final } \\
\text { statement } \\
\text { NCP) }\end{array}$ & $\begin{array}{l}\text { Hybrid (fact-finding/ } \\
\text { investigation and } \\
\text { dialogue-based) }\end{array}$ & Dialogue-based & $\begin{array}{l}\text { Dialogue-based } \\
\text { (between ad hoc } \\
\text { multi-stakeholder } \\
\text { group) }\end{array}$ & Dialogue-based \\
\hline $\begin{array}{l}\text { Substantive } \\
\text { outcomes }\end{array}$ & $\begin{array}{l}\text { Final statement } \\
\text { NCP with assess- } \\
\text { ment of insuffi- } \\
\text { cient consultation } \\
\text { but no evidence } \\
\text { of bribery and rec- } \\
\text { ommendations on } \\
\text { consultation, dis- } \\
\text { closure, transpar- } \\
\text { ency and the } \\
\text { company-based } \\
\text { grievance mecha- } \\
\text { nism }\end{array}$ & $\begin{array}{l}\text { Strengthening } \\
\text { of human } \\
\text { rights policy } \\
\text { and formalized } \\
\text { human rights } \\
\text { due diligence }\end{array}$ & $\begin{array}{l}\text { Continuous dialogue } \\
\text { between parties (and } \\
\text { as a result of the inves- } \\
\text { tigations a stop order } \\
\text { by authorities inducing } \\
\text { the reduction and } \\
\text { restoration of environ- } \\
\text { mental damage) }\end{array}$ & $\begin{array}{l}\text { Improvements in } \\
\text { care of those suf- } \\
\text { fering from CKD } \\
\text { (and their fami- } \\
\text { lies), income-gen- } \\
\text { erating projects } \\
\text { to support alter- } \\
\text { native livelihood } \\
\text { for those suffer- } \\
\text { ing from CKD }\end{array}$ & $\begin{array}{l}\text { Monetary redress } \\
\text { (additional sever- } \\
\text { ance paid) }\end{array}$ & $\begin{array}{l}\text { GMOU (durable } \\
\text { agreement with } \\
\text { consistent single } \\
\text { platform for } \\
\text { company/com- } \\
\text { munity dialogue } \\
\text { to identify and } \\
\text { resolve issues) }\end{array}$ \\
\hline $\begin{array}{l}\text { Outcome } \\
\text { retrospec- } \\
\text { tive or for- } \\
\text { ward look- } \\
\text { ing }\end{array}$ & Both & $\begin{array}{l}\text { Forward look- } \\
\text { ing }\end{array}$ & Both & Forward looking & Retrospective & Forward looking \\
\hline Acceptance & Unclear & Both parties & $\begin{array}{l}\text { Both parties (however, } \\
\text { reduction and restora- } \\
\text { tion of environmental } \\
\text { damage government } \\
\text { induced) }\end{array}$ & Both parties & All parties & Both parties \\
\hline $\begin{array}{l}\text { Implemen- } \\
\text { tation }\end{array}$ & $\begin{array}{l}\text { No enforcement } \\
\text { or monitoring }\end{array}$ & $\begin{array}{l}\text { Monitoring by } \\
\text { NGO }\end{array}$ & $\begin{array}{l}\text { Monitoring by human } \\
\text { rights commission } \\
\text { (however, only during } \\
\text { process) and stop } \\
\text { order from govern- } \\
\text { ment }\end{array}$ & $\begin{array}{l}\text { No enforcement } \\
\text { or monitoring }\end{array}$ & $\begin{array}{l}\text { Severance paid } \\
\text { (no further } \\
\text { enforcement or } \\
\text { monitoring } \\
\text { needed) }\end{array}$ & $\begin{array}{l}\text { No enforcement } \\
\text { or monitoring }\end{array}$ \\
\hline
\end{tabular}

judicial and judicial mechanisms that stakeholders are engaged in and/or can contribute to effective remedy in combination with the outcomes of other processes.

These reflect a mix of objective and subjective considerations. Arguably, the more of them that are fulfilled, the more likely it is that the remedial outcome will be generally deemed to be effective. Alternatively, for some observers the presence of just one of these elements might be sufficient to consider an outcome effective or some might not be deemed relevant elements in every case. For example, if every violation is addressed through compensation, this might not result in meaningful change in the conduct of the company or address of the underlying issues. A high number of complaints about similar issues over time might indicate a failure to address underlying causes of complaints. Hence, remedy outcomes might be more effective in certain cases if they drive a change in the relationship between company and community and address power imbalances. Furthermore, cases differ and therefore the elements that 
are conceived to be relevant indicators might differ with them. Obviously, the remedies offered should be appropriate; for example, they should respond to the needs of the community and not be unnecessarily costly in order to be effective. However, different elements might play a (more important) role in order to assess this along different cases.

Furthermore, it is not always easy to assess whether these elements have been met. For example, operational-level grievance mechanisms might even lack information about the number of complaints they are handling and the percentages that are resolved. If such (basic) information is lacking, it is going to be difficult to find more sophisticated information needed to assess the compliance with the mentioned elements. Beside this, assessing whether an outcome is human rights compatible is not easy in practice. One probably needs proxy indicators (such as stakeholder perspectives) to assess this element.

\section{Conclusion}

It is important to assess the effectiveness of the remedy outcomes of non-judicial mechanisms. Perceptions of the effectiveness of the outcomes are likely to influence the trust that stakeholders have in the mechanisms themselves and their usage. For example, if impacted communities feel a non-judicial mechanism is effective, they are more likely to use it. Beside this, companies might be interested to assess whether certain non-judicial mechanisms are effective in order to decide whether or not to use (or implement) them. If the effectiveness of mechanisms might be established, this might incentivize the (to date not very broad) usage (or implementation) of them by companies. Furthermore, the effectiveness of non-judicial mechanisms might convince NGOs that they do not (by and large) result in 'watered down' outcomes in comparison with judicial mechanisms.

Hereinabove, I have suggested some elements of effectiveness of the outcomes of non-judicial mechanisms. However, more research (especially with stakeholders involved in these mechanisms) is needed to assess whether these are the most viable ones or whether other elements might be more useful and easy to assess. Besides that, it has to be established whether these elements are useful in every case/mechanism or whether the elements of effectiveness range along different cases and/or mechanisms. Obviously, it would be preferable if overarching elements might be determined. This facilitates the comparison by stakeholders between the effectiveness of the outcomes of non-judicial mechanisms.

\section{Bibliography}

L.C. Backer, "Rights and Accountability in Development (Raid) v Das Air and Global Witness v Afrimex: Small Steps Toward an Autonomous Transnational Legal System for the Regulation of Multinational Corporations", 10 Melbourne Fournal of International Law 2009, pp. 30-38, retrieved from <http:// papers.ssrn.com/sol3/papers.cfm?abstract_id $=1427883>$.

B. Linder, K. Lukas \& A. Steinkellner, The Right to Remedy, Vienna, Ludwig Boltzmann Institute, 2013, retrieved from $<$ http://bim.lbg.ac.at/en/news/extrajudicial-complaintmechanisms-conflict-resolution-between-business-andhuman-rights- $0>$.

A. Onuoha \& M. Barendrecht, Issues Betmeen Company and Community, Towards Terms of Reference for CSR-Conflict Management Systems, HiiL report, The Hague, December 2012.

C. Rees, Access to Remedies for Corporate Human Rights Impacts: Improving Non-judicial Mechanisms, CSRI Report No. 32, Cambridge, MA, John F. Kennedy School of Government, Harvard University, November 2008.

C. Rees, Grievance Mechanisms for Business and Human Rights, CSRI Working Paper No. 40, Cambridge, MA, John F. Kennedy School of Government, Harvard University, January 2008.

C. Rees \& D. Vermijs, Mapping Grievance Mechanisms in the Business and Human Rights Arena, Corporate Social Responsibility Initiative, Cambridge, MA, John F. Kennedy School of Government, Harvard University, January 2008.

M. Scheltema, "Does CSR Need More (Effective) Private Regulation in the Future?", in S. Muller et al. (eds.), The Lam of the Future and the Future of Lam II, The Hague, Torkel Opsahl, 2012a.

M. Scheltema, "Helpt arbitrage bij geschilbeslechting op het gebied van maatschappelijk verantwoord ondernemen", 61 Tijdschrift voor Arbitrage, 2012b, pp. 189-194.

W. van Genugten \& N. Jägers, "Protecting the Victims of the Privatization of War", in R. Letschert \& J. van Dijk (eds.), The New Faces of Victimhood, Dordrecht, Springer, 2011.

W. van Genugten, R. van Gestel, M. Groenhuijsen \& R. Letschert, "Loopholes, Risks and Ambivalences in International Lawmaking: The Case of a Framework Convention on Victims' Rights", in F.-W. Winkel, P.C. Friday, G.E. Kirchhoff \& R.M. Letschert (eds.), Victimization in a Multi-disciplinary Key: Recent Advances in Victimology, Nijmegen, Wolf Legal Publishers, 2009.

E. Wilson \& E. Blackmore (eds.), Dispute or Dialogue? Community Perspectives on Company-Led Grievance Mechanisms, London, IIED, 2013, retrieved from <http://pubs.iied.org/ 16529IIED.html>. 